\title{
THE HERBARIUM OF RUDOLF M. SCHUSTER: UNLOCKING OVER A HALF A CENTURY OF BOTANICAL EXPLORATION
}

\section{ГЕРБАРИЙ РУДОЛЬФА М. ШУСТЕРА: НАКОНЕЦ-ТО СТАЛИ ДОСТУПНЫ МАТЕРИАЛЫ БОЛЕЕ ЧЕМ ПОЛУВЕКОВЫХ ИССЛЕДОВАНИЙ}

\author{
MATT VON KONRAT ${ }^{1}$, JOHN J. ENGEL ${ }^{1}$, LAURA BRISCOE ${ }^{2}$, YARENCY RODRIGUEZ ${ }^{1}$, \\ MIKE NIEZGODA ${ }^{3}$, ANDREA SASS-GYARMATI ${ }^{4}$, TAMÁS PÓCS ${ }^{4}$, DENISE PINHEIRO DA COSTA ${ }^{5}$, \\ DAVID H. WAGNER ${ }^{6}$, MATT A.M. RENNER ${ }^{7}$, JORGE ENRIQUE GIL NOVOA ${ }^{5}$, JUAN LARRAÍN ${ }^{8}$, \\ MEREIA TABUA ${ }^{9}$, HANNAH RANFT $^{10}$, JENNIFER LE ${ }^{1}$, DAVID GLENNY ${ }^{11}$, ROBIN LONG ${ }^{11}$, \\ GENEA M. PITTS ${ }^{12}$, NKOSI EVANS ${ }^{1}$, ROBERT SALM ${ }^{1} \&$ VOLUNTEERS OF THE COLLECTIONS CLUB ${ }^{1}$ \\ МЭТТ ФОН КОНРАТ ${ }^{1}$, ЛАУРА БРИСКО ${ }^{2}$, ЯРЕНСИ РОДРИГЕС ${ }^{1}$, ДЖОН Д. ЭНГЕЛ ${ }^{1}$, \\ МАЙК НЕЗГОДА ${ }^{3}$, АНДРЕА САСС-ГИАРМАТИ ${ }^{4}$, ТАМАШ ПОЧ ${ }^{4}$, ДЕНИЗЕ ПИНХЕЙРО ДА КОСТА ${ }^{5}$, \\ ДЭВИД Г. ВАГНЕР ${ }^{6}$, МЭТТ А.М. РЕННЕР ${ }^{7}$, ХОРХЕ ЭНРИКЕ ГИЛ НОВОА $^{5}$, ХУАН ЛАРРАЙН $^{8}$, \\ МЕРЕЙЯ ТАБУА $^{9}$, ХАННА РАНФТ $^{10}$, ДЖЕННИФЕР ЛИ ${ }^{1}$, ДЭВИД ГЛЕННИ ${ }^{11}$, РОБИН ЛОНГ ${ }^{11}$, \\ ГЕНЕЯ М. ПИТТС ${ }^{12}$, НКОСИ ЭВАНС ${ }^{1}$, РОБЕРТ САЛЬМ ${ }^{1}$, ВОЛОНТЕРЫ КЛУБА КОЛЛЕКТОРОВ ${ }^{1}$
}

Abstract

The esteemed scholar, bryologist, and botanist, Prof. Rudolf M. Schuster, was a prolific collector and author of over 300 scientific publications. His staggering number of collections, reliably estimated at over 80,000 specimens, span almost six decades of fieldwork in over 38 countries. For almost his entire career, over two thirds of R. M. Schuster's herbarium was largely inaccessible at his private residence. In 2013 his herbarium, in its entirety, was transferred to Field Museum. A detailed overview of the herbarium of R. M. Schuster is provided, including a description of the collections, the geographical extent, and status of curation and accessibility. This is complemented by tabulations and summary data representing the number of liverwort taxa R. M. Schuster described during his career and appended with a complete list of publications associated with liverworts and hornworts. Supplementary material provides a complete list of validly and legitimately published names at all ranks, from species to order, coupled with their original publication. This is the only publication that attempts to centralize and summarize the collections, publications, and exhaustive list of described taxa representing the career of the pre-eminent scientist, Prof. R. M. Schuster.

Резюме

Выдающийся ученый, бриолог, ботаник, проф. Р.М. Шустер был выдающимся коллектором и автором более 300 научных трудов. За почти 60 лет исследований он собрал в 38 странах более 80,000 образцов. Почти все время две трети его гербария, хранившиеся у него дома, были малодоступны. В 2013 его гербарий был передан Музею естественной истории имени Филда в Чикаго. В статье приводится подробный обзор гербария Шустера, самих образцов, географии сборов, состояния, работы с ними и, наконец, доступности. Приводится полная библиография трудов Шустера по печеночникам и антоцеротовым, дополнительные материалы включают полные каталоги описанных им таксонов, от порядков до таксонов внутривидового ранга. В этой публикации наиболее подробно обобщены данные о научном наследии великого ученого Рудольфа Матиаса Шустера.

KEYWORDS: Rudolf M. Schuster, herbarium, collections, liverworts, taxa, volunteers

\footnotetext{
1 - Gantz Family Collections Center, Field Museum, 1400 S. DuSable Lake Shore Drive, Chicago, IL 60605, U.S.A.

2 - Cryptogamic Herbarium, New York Botanical Garden, 2900 Southern Boulevard, Bronx, NY 10458, U.S.A.

3 - University of Wisconsin, 1550 Engineering Drive Madison, WI 53706, U.S.A.

4 - Botany Department, Institute of Biology, Eszterházy Károly Catholic University, Eger, Pf. 43, H-3301, Hungary

5 - Instituto de Pesquisas Jardim Botbnico do Rio de Janeiro, Rua Pacheco Lего 915, 22460-030 Rio de Janeiro, Brazil

6 - Northwest Botanical Institute, PO Box 30064, Eugene, Oregon 97403, U.S.A.

7 - National Herbarium of New South Wales, Royal Botanic Garden and Domain Trust, Mrs. Macquaries Road, Sydney, NSW 2000, Australia.

8 - Instituto de Biologна, Pontificia Universidad Catylica de Valparaнso, Av. Universidad 330, Curauma, Valparaнso, Chile

9 - University of the South Pacific, Suva, Fiji

10 - University of Minnesota Duluth, Minnesota, U.S.A.

11 - Allan Herbarium, Manaaki Whenua, PO Box 69-040, Lincoln 7640, New Zealand

12 - Shapiro+Raj, 425 S. Financial Pl. Suite 3250, Chicago, IL 60605, U.S.A.
} 


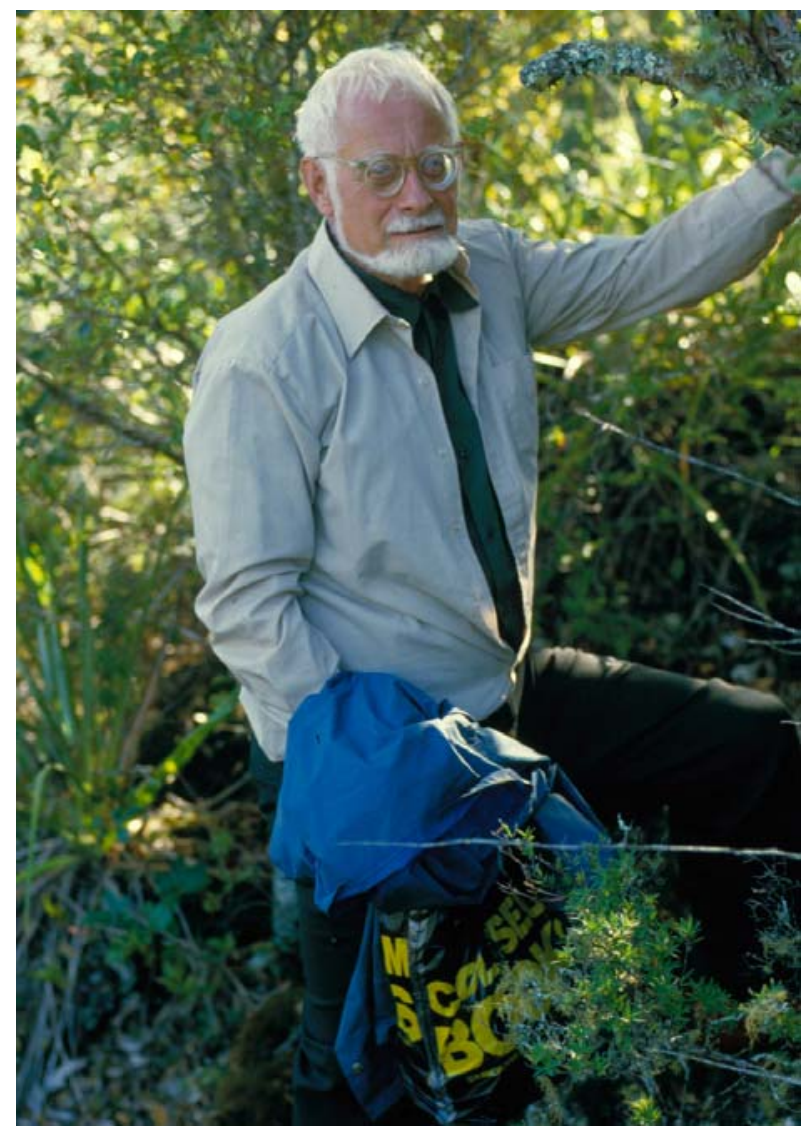

Fig. 1. Prof. Rudolf M. Schuster collecting on Rangitoto Island in the Hauraki Gulf, North Island, New Zealand in 1984. Photo Dr. John E. Braggins.

\section{INTRODUCTION}

Dr. Schuster, Professor Schuster, or Rudy - to all who knew him - was born April 8, 1921, in Altmühldorf, Germany (Fig. 1). Rudolf M. Schuster was an eminent botanist, hepaticologist, scholar, and world explorer, with a stunning career that spanned over six decades and represented one of the foremost classical scholars of our time in botany. Over the course of his career, he was awarded two Guggenheim Fellowships and a Fulbright U.S. scholar grant to conduct botanical research in New Zealand. His fieldwork took him all over the world and led to numerous scientific discoveries and novelties from the rank of form to order. It is difficult to name another contemporary botanist who discovered this much new diversity of a major clade of land plants (Qiu et al., 2013). Schuster's research has had far reaching implications beyond bryology including his being one of the first botanists who recognized the importance of Wallace's Line in plant biogeography (Schuster 1972).

The International Association for Plant Taxonomy awarded him the Engler Medal in Silver in 1992 recognizing his illustrious scientific contributions. Since his passing on the 16th of November 2012, there have been several obituaries and biographies that provide an indepth account of R. M. Schuster's life, from early childhood to his death, e.g., Qiu et al. (2013) and Long (2015).
Earlier, Engel \& Klekowski (1988) provided an extensive account of the life and travels of R. M. Schuster as part of a Festschrift in celebration of his distinguished scholarship. Readers are referred to these accounts for his biographic background.

The object of this paper is to provide, for the first time, a detailed account of his exhaustive herbarium, and centralized information about all of his publications as they relate to liverworts and hornworts (Appendix 1) as well providing summary information about new taxa to science that he validly and legitimately described (Table 1). This is supplemented by a complete list, as we know it, of all taxa representing all ranks; this is confined to validly and legitimately names coupled with the original publication (Supplement 1). Our ambition with this paper is to provide thorough information about this important collection along with his exhaustive publications and novelties, which we hope will stimulate future research and continue the legacy of Prof. Rudolf M. Schuster.

\section{OVERVIEW OF THE HERBARIUM OF R. M. SCHUSTER}

In 1982, Field Museum purchased the entire herbarium of R. M. Schuster through the efforts of now Emeritus Curator John Engel. As part of the contractual agreement, the vast majority of R. M. Schuster's herbarium remained at his residence up until his passing to enable him to pursue his research. However, some 25,000 specimens, mainly from North America, were physically transferred to Field Museum where they were curated and databased. It was not until February 2013, that Field Museum acquired the remaining portion of what was then estimated to be approximately 35,000 specimens (Fig. 2).

Upon the packing and transfer of the herbarium of $\mathrm{R}$. M. Schuster, it was abundantly clear that over a third of the collection was in critical need of curation ranging from specimens in original newspaper and brown paper bags to original collecting packets (Fig. 3C, D, F). There was also vital type material that required urgent attention, some of which was in glass vials and on microscopic slides. This was a major undertaking. Shortly after the acquisition, Field Museum Collections Spending Fund and later in 2015 the National Science Foundation (NSF Award No. 1115002) provided support for curation, sorting, barcoding, databasing and digitizing significant portions of the collection in order to make it accessible.

Throughout the past eight years, the collection has been widely used by visiting scholars and through loan activity. This period was also concurrent with a largescale databasing initiative - the NSF funded Thematic Collection Network North American lichen and bryophyte consortium; a project imaging about 2.3 million North American lichen and bryophyte specimens from more than 60 U.S. herbaria to address questions of how species distributions change after major environmental events, both in the past and projected into the future. With the collection of R.M. Schuster being worldwide in scope, this effort continues with a similar NSF funded 


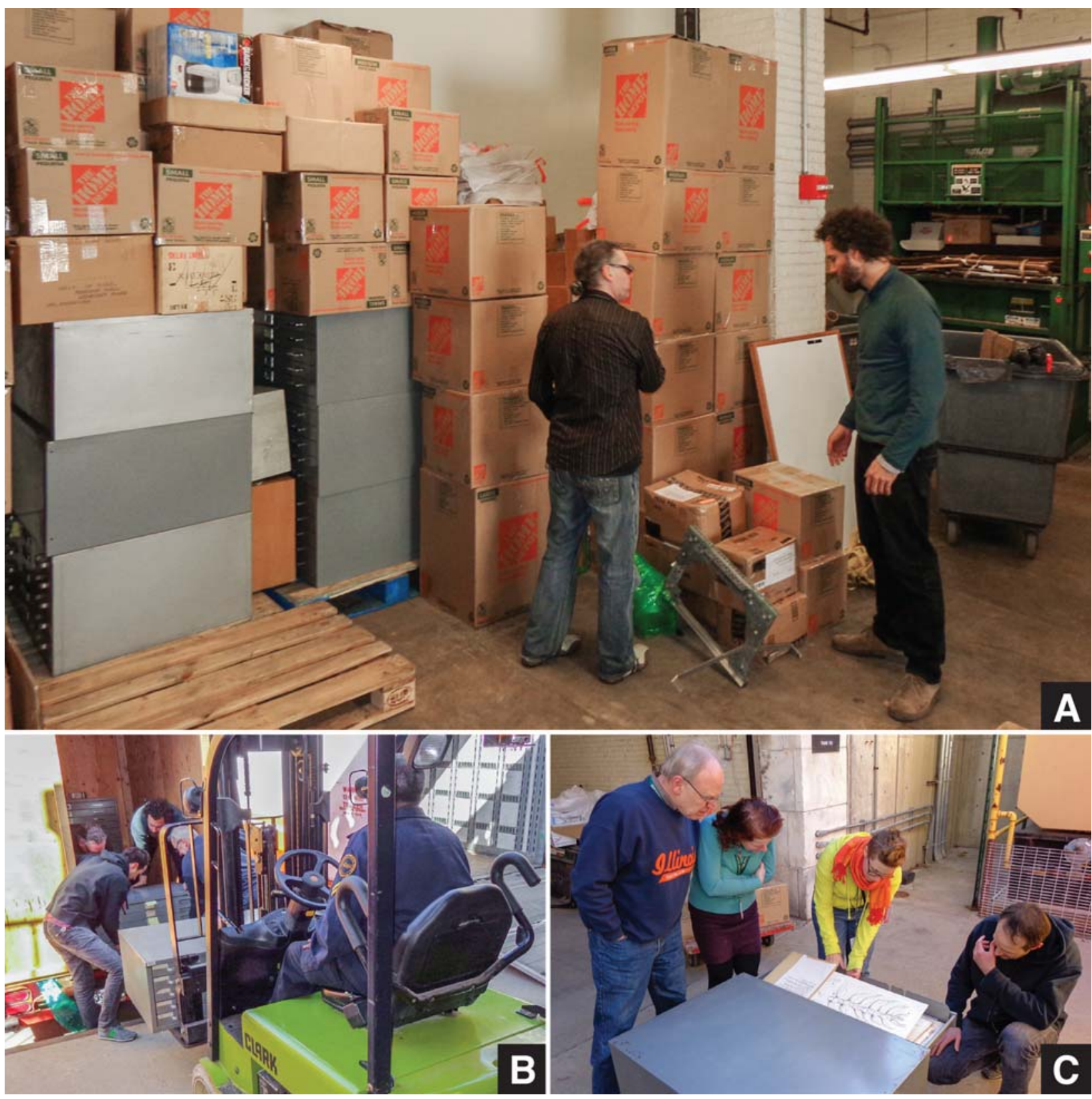

Fig. 2. Unloading of the herbarium of R. M. Schuster at the loading dock of Field Museum. A. Matt von Konrat and Juan Larraín with the scores of boxes of specimens. B. Matthew Nelson, Matt von Konrat, Juan Larraín, and John Engel manoeuvre the steel drawers full of original illustrations with Terry Bruce. C. Laura Briscoe and staff marvel at the original plates.

digitization effort - Building a global consortium of bryophytes and lichens: keystones of cryptobiotic communities (NSF Award No. 2001509). This latter digitization effort offers the opportunity to also capture digital images of the physical specimen itself as well as label data.

THE UNLOCKING OF SIX DECADES OF COLLECTIONS

The following describes the effort from several key individuals, including co-authors Laura Briscoe, Yarency Rodriguez, Mike Niezgoda with numerous assistance from volunteers and interns throughout the past eight years. Originally, ten's of thousands of specimens were in paper bags and newspaper (Fig. 3 C, D, E, F). Typically, R. M. Schuster would collect specimens in packets in the field, transfer these to individual newspaper sheets then into bundles, with locality information for later curation and processing (Fig. 3E, F). An estimated 30,000 specimens had already been at least partially curated, labelled and packeted (Fig. 3B). Over 20,000 specimens were in critical need to be transferred from newspaper to packets for accessibility. This was largely achieved by assistance from volunteers, including Field Museum Collection Club members - a group of volunteers that meet every quarter (Fig. 4A). Through these combined efforts spanning several years, the collections have finally become accessible to scientists worldwide that have otherwise been largely inaccessible for several decades. 


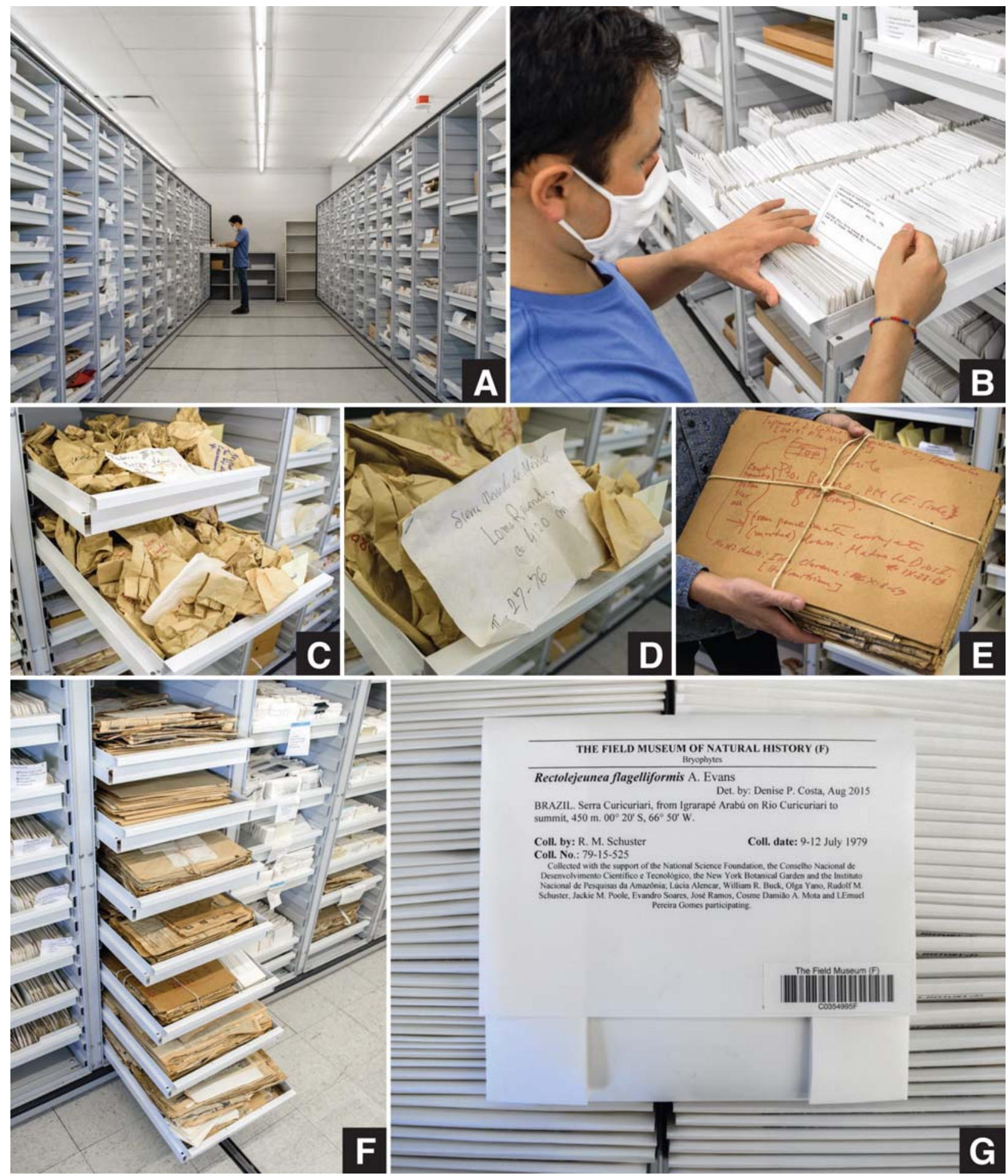

Fig. 3. A. One of two aisles dedicated to the herbarium of R. M. Schuster herbarium. B. Jorge Enrique Gil Novoa, from Colombia, perusing the 1000's of specimens that were already adequately housed, labelled and identified to various degrees. C., D. Significant collections remain in brown paper collecting bags, have not been identified but have valuable label data. E. Bundle of specimens in newspaper with locality data affixed to the "lot" or bundle. F. Over 20,000 specimens were housed in newspaper. G. The final curated specimen with label printed directly on archival packet, barcoded and databased.

Figure 4B, C \& D indicate the final curated specimens. Many specimens came with adequately archived label data that was glued directly onto archival packets (3B).

A complete inventory of R. M. Schuster's herbarium was performed by Collection Club members after it had been immaculately sorted and curated by staff and volunteers over the years. A staggering 58,974 specimens were counted and inventoried. The lots themselves had been earlier carefully surveyed by Laura Briscoe and Mike Niezgoda to determine level of curation, e.g., presence/absence 


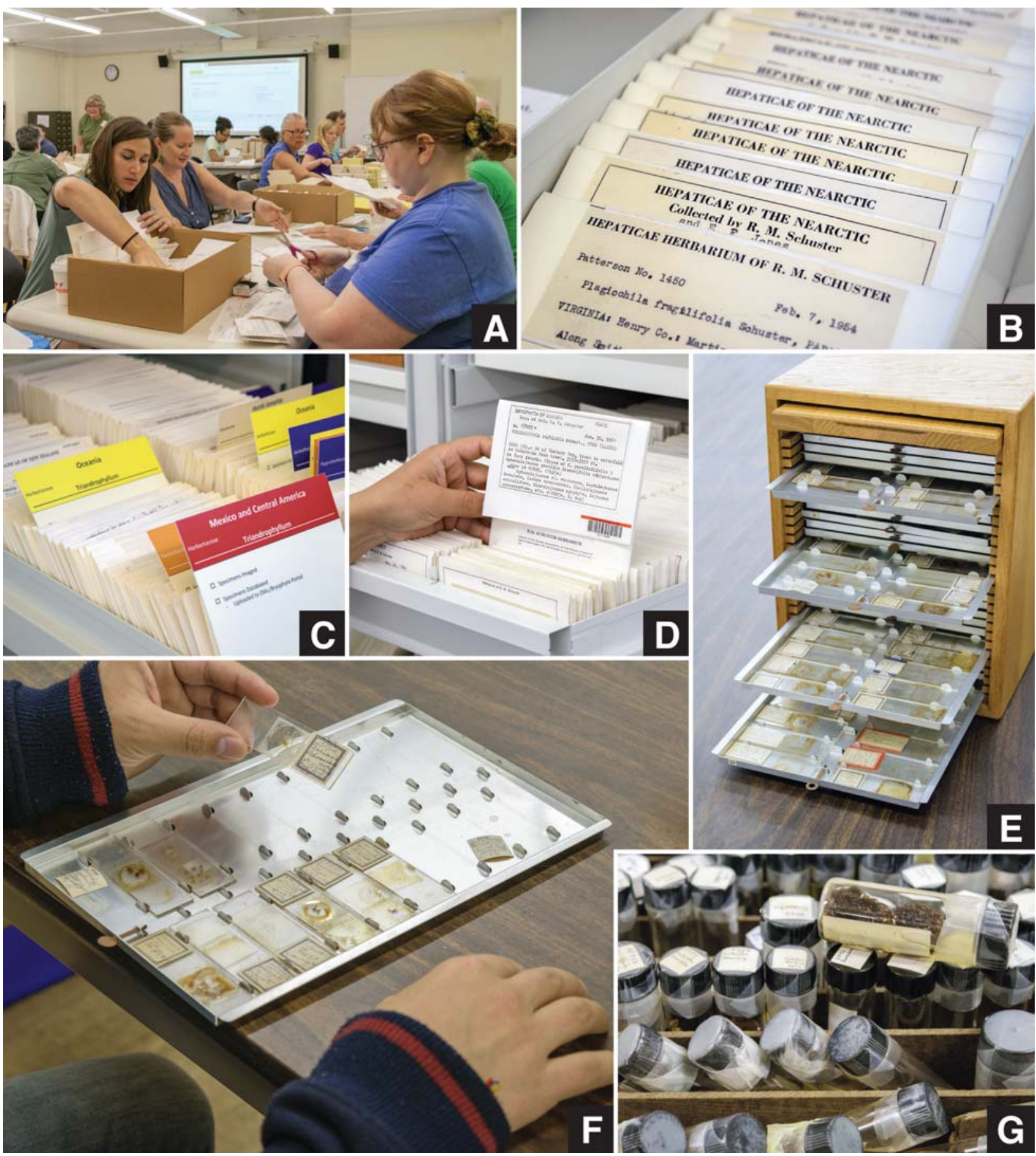

Fig. 4. A. Collections Club members that significantly contributed to unlocking the collections of R. M. Schuster exemplifies community science efforts. B., D. Original labels glued on to archival packets. labels C. Specimens housed in the main herbarium by geography. E, F. Over 600 microscopic slides; some have been salvaged by Juan Larrain. G. Over 500 vials of material in FAA have been inventoried.

of label data, identification, and level of processing in order to establish priorities. Together with material already in the main herbarium we count 80,273 specimens representing collections from 35 countries (Fig. 5). This includes approximately 5,000 specimens that are either gifts, exchange or exsiccate sets. Unfortunately, close to 10,000 specimens have either no label data at all, or limited label data, or only the country is known.
The R. M. Schuster collection also has a significant number of specimens in FAA glass vials (549) and important microscopic slides (over 600) that have been inventoried and available upon request (Fig. 4E, F, G). Some the newly described species by R. M. Schuster were only of reported from the type collection from slides or FAA (von Konrat et al. 2006) so these represent a valuable resource. Field Museum also has over 1,000 of R. 


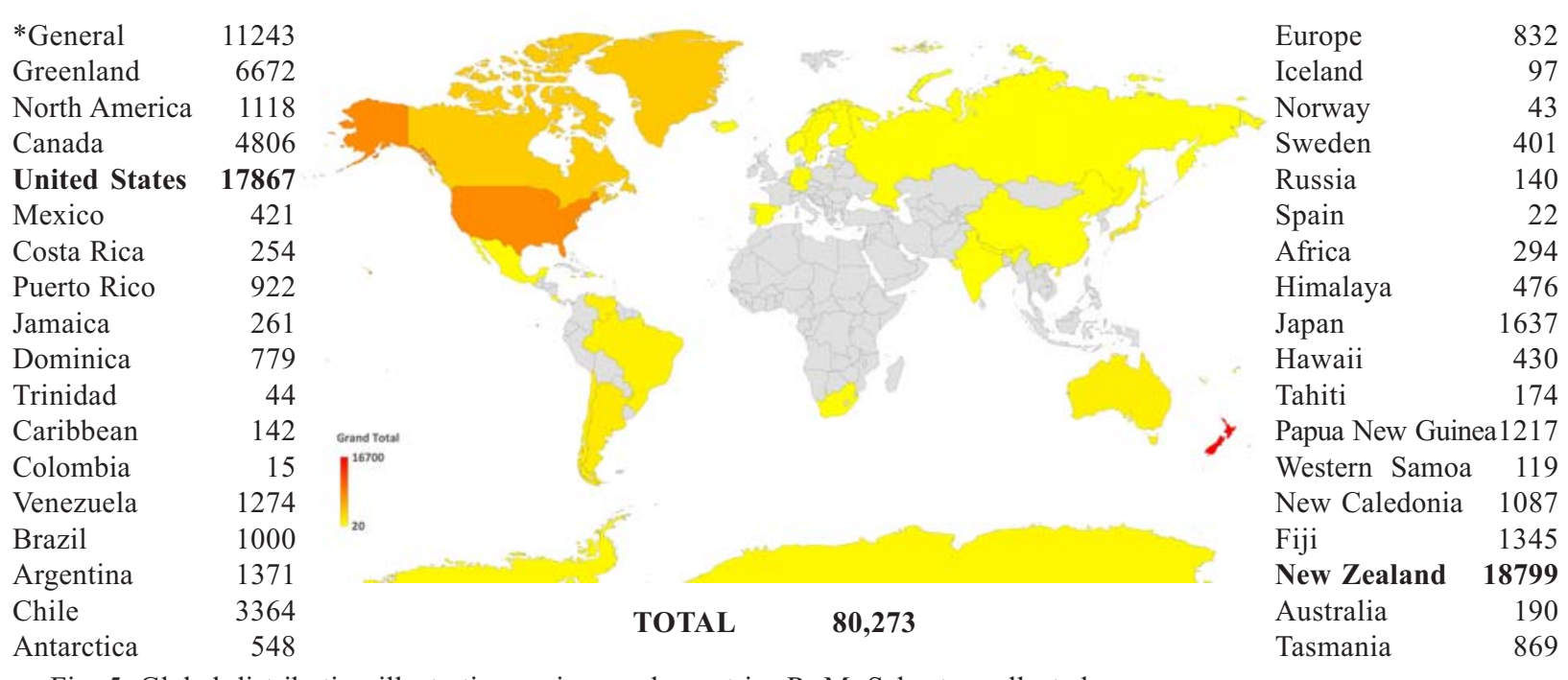

Fig. 5. Global distribution illustrating regions and countries R. M. Schuster collected.

M. Schuster's original illustration plates that have yet to be completely inventoried, although John Engel has done a partial analysis. The collection also has 399 type fragments or "collectotypes" from various type collections R. M. Schuster studied.

Herbaria have long been recognized as a major frontier for species discovery and distribution patterns with studies indicating a vast majority of undescribed species that have already been collected and are stored in herbaria (Bebber et al., 2010). This also extends to range extensions and distribution patterns. Since 2013, the curation of R. M. Schuster's herbarium has contributed to a plethora of such discoveries, and in many cases his collections remain unique because of the extremely isolated regions collected and the era in which they were collected. Some noteworthy examples include the first bryofloristic analysis for a Brazilian mountain in the Amazonian rainforest (Costa et al., 2017), ongoing floristic studies of New Zealand, including the first ever modern liverwort and hornwort flora for the region (Engel \& Glenny 2019a,b), many new records from Fiji (von Konrat et al. 2014, Pócs et al. 2018), and new species to science from New Caledonia (Larraín et al., 2018). These examples and more underscore that effort, funding, and research focus should, therefore, be directed as much to examining extant herbarium material as collecting new material in the field (Bebber et al. 2010).

\section{ENUMERATION OF TAXA DESCRIBED BY R. M. SCHUSTER}

Rudy's major contribution to botany and hepaticology lies in the astounding new diversity of liverworts he added to our knowledge. Mostly by himself and through collaboration with a small number of colleagues, he described 455 taxa at the rank of species or below, 97 genera and 343 infrageneric taxa, 75 higher taxa, including 16 families, 16 suborders and one order (Table 1). These discoveries were made in his land-combing floristic surveys of hepatics in eastern North America, Greenland, New
Zealand, and other parts of the world. As noted by Godfrey \& Godfrey (2012), R. M Schuster particularly emphasized the importance of examining hepatic specimens while they are still fresh, recording taxonomic characters associated with oilbodies - cellular structures that typically disappear upon drying. A complete list of all taxa described by R. M. Schuster is provided as Supplementary Material, which includes the original citation. This exhaustive list of over 900 taxa is restricted to those that were validly and legitimately published. As commented by Godfrey \& Godfrey (2012) and others, R. M. Schuster had had little or no patience with the practice of designating new taxa through the exercise of nomenclatural revision.

Table 1. Taxa described by R.M. Schuster (see complete lists in Summplementary Materials)

$\begin{array}{lrlr}\text { Forms } & 23 & \text { Genera } & 97 \\ \text { Varieties } & 73 & \text { Tribes } & 8 \\ \text { Subspecies } & 57 & \text { Subfamilies } & 34 \\ \text { Species } & 302 & \text { Families } & 16 \\ \text { Subsections } & 40 & \text { Suborders } & 16 \\ \text { Sections } & 181 & \text { Order } & 1 \\ \text { Subgenera } & 122 & & \end{array}$

\section{BIBLIOGRAPHY OF R. M. SCHUSTER}

R. M. Schuster has authored or co-authored 256 publications that focus on bryology. Perhaps the most noteworthy are the multi-volume books: the Hepaticae and Anthocerotae of North America, east of the hundredth meridian (The Big Green), and three volumes of Austral Hepaticae. These floras are not mere conventional compilations of taxonomic diversity, but are also encyclopedic treatments of liverworts and hornworts as well as their biology (Qiu et al., 2013). Engel et al. (2015) previously provided this exhaustive list of publications, which we slightly modify and include here as Appendix 1 to provide a central source of R. M. Schuster's scholarly contribution to bryology. 


\section{ACKNOWLEDGMENTS}

The Biodiversity Heritage Library is acknowledged for the facility they provide that has greatly accelerated our efforts. The generous support by the National Science Foundation (Award No.'s 1145898, 1115002 1458300, 1541506, 2001509 and 0531730 ) is gratefully acknowledged. We also recognize the support of the Museum Collection Spending Fund, administered by Field Museum, as well as curatorial support provided by L. Kawasaki, and A. Balla (Field Museum). Deep gratitude is owed to Anders Hagborg (Field Museum) and Lars Söderström (Norwegian University of Science and Technology) who very generously prepared the supplementary material and summary statistics regarding novelties. Many volunteers and interns as well as dozens of members of the Field Museum Collections Club - a group of volunteers that meet every quarter. Without the countless hours of assistance for over 80,000 specimens the herbarium of R.M. Schuster would not be in the accessible state that it now is.

\section{LITERATURE CITED}

BEBBER, D.P., M.A. CARINE, J.R. WOOD, A.H. WORTLEY, D.J. HARRIS, G.T. PRANCE, G. DAVIDSE, J. PAIGE, T.D. PENNINGTON, N.K. ROBSON, \& R.W. SCOTLAND. 2010. Herbaria are a major frontier for species discovery. - Proceedings of the National Academy of Sciences 107(51): 22169-2217.

COSTA, D.P., D.F. PERALTA, W.R. BUCK, J. LARRAÍN, \& M. VON KONRAT. 2017. Serra do Curicuriari, Amazonas state, Brazil: the first bryofloristic analysis for a Brazilian mountain in the Amazonian forest. - Phytotaxa 303: 201-217.

ENGEL, J. J. \& D. S. GLENNY. 2019a. A Flora of the Liverworts and Hornworts of New Zealand, Volume 2. - Missouri Botanic Gardens Press, St Louisá 750 pp.
ENGEL, J. J. \& D.S. GLENNY. 2019b. A Flora of the Liverworts and Hornworts of New Zealand, Volume 3. - Missouri Botanic Gardens Press, St Louis, $672 \mathrm{pp}$.

ENGEL, J.J. \& A. KLEKOWSKI. 1988. The life and travels of a twentieth century plant explorer; together with a comprehensive bibliography of R.M. Schuster's publications in bryology. - Beihefte zur Nova Hedwigia 90: 1-15.

ENGEL, J.J., M. VON KONRAT \& Y. RODRIGUEZ. 2015. The Bryological Works of Rudolf M. Schuster. - Plant Science Bulletin 59: 45-54.

GODFREY, J. \& G. GODFREY. 2012. Remembering Rudolf M. "Rudy" Schuster, Ph.D. (1921-2021). - Botanical Electronic News 461 [Accessed at https://www.ou.edu/cas/botany-micro/ben/ben461.html on December 09, 2021]

LARRAÍN, J., M. VON KONRAT, P. NGUYEN, B.E. CARTER, B. AGÜERO, M. TABUA, M. \& L, THOUVENOT. 2018. Unveiling the enigmatic and ambiguous: A new Frullania species from New Caledonia. - Bryophyte Diversity and Evolution 40: 104-112.

LONG, D.G. 2015. Rudolf M. Schuster (1921-2012). - Journal of Bryology 37: 151-155.

SCHUSTER, R.M. 1972. Continental movements, "Wallace's line" and Indomalayan-Australasian dispersal of land plants - some eclectic concepts. - Botanical Review 38: 3-86.

PÓCS, T., A. SASS-GYARMATI, M. VON KONRAT, \& L. BRISCOE. 2018. Bryophytes from the Fiji Islands, IX. Liverwort Collections Made by R.M. Schuster. - Cryptogamie, Bryologie 39: 169-176.

QIU, Y.-L., M. VON KONRAT, \& J.J. ENGEL. 2013. In Memoriam. Rudolf Mathias Schuster. 1921-2012. - Plant Science Bulletin 59: 165-168.

VON KONRAT, M., J. ENGEL, M. KATAFONO, L. SÖDERSTRÖM, E. COOPER, C. DELAVOI, A. HAGBORG, M. RENNER, L. BRISCOE, T. PÓCS, J. BRAGGINS, S.H. TUIWAWA, A.N. NAIKATINI, \& M. TUIWAWA. 2014. Unlocking collections: New records of Lepidoziaceae (Marchantiophyta) for the islands of Fiji. - Telopea Journal of Plant Systematics 17: 403-413.

\section{COMPLETE BIBLIOGRAPHY OF RUDOLF MATTHIAS SCHUSTER ON BRYOPHYTES}

SCHUSTER, R.M. 1949. Notes on Nearctic hepaticae I. Dianthelia steerei gen. et sp. n., a critical endemic of the Appalachians, with notes on the relationships of the genus. - The Bryologist 52(3): 102-120. https:// doi.org/10.2307/3238941

SCHUSTER, R.M. 1949. The ecology and distribution of hepaticae in Central and Western New York. - The American Midland Naturalist 42(3): 513-712. https://doi.org/10.2307/2421930

SCHUSTER, R.M. 1950. The hepaticae of the east coast of Hudson Bay: (notes on Nearctic hepaticae, II). Ottawa: the Minister of Resources and Development.

SCHUSTER, R.M. 1951. Notes on Nearctic hepaticae III. A conspectus of the family Lophoziaceae, with a revision of the genera and subgenera. - The American Midland Naturalist 45(1): 1-117. https://doi.org/ $10.2307 / 2421711$

SCHUSTER, R.M. 1951. Notes on Nearctic hepaticae IV. Scapania spitzbergensis and Scapania convexula in North America. - The Bryologist 54(3): 162-180. https://doi.org/10.2307/3240300

SCHUSTER, R.M. 1952. Notes on Nearctic hepaticae. V. The status of Lophozia gracillima Buch and its relationships to Lophozia longidens, Lophozia porphyroleuca and Sphenolobus ascendens. - The Bryologist 55(3): 173-185. https://doi.org/10.2307/3239846

SCHUSTER, R.M. 1953. Boreal hepaticae a manual of the liverworts of Minnesota and adjacent regions. - The American Midland Naturalist 49(2): 257-684. https://doi.org/10.2307/2422089

SCHUSTER, R.M. 1953. Notes on Nearctic hepaticae VII. Lophozia (Dilophozia) latifolia sp. nov. - The Bryologist 56(4): 257-276. https://doi.org/10.2307/3240457
SCHUSTER, R.M. 1954. Notes on Nearctic hepaticae. VIII. Lejeuneaceae Holostipae of North America. - Journal of the Elisha Mitchell Scientific Society 70(1): 42-56.

SCHUSTER, R.M. \& S. HATTORI. 1954. The oil-bodies of the hepaticae. II. The Lejeuneaceae. - Journal of the Hattori Botanical Laboratory 11: 11-86.

SCHUSTER, R.M. 1955. Notes on Nearctic hepaticae. IX. The relationships of the genus Gyrothyra. - The Bryologist 58(2): 137-141. https://doi.org/10.2307/3240429

SCHUSTER, R.M. 1955. North American Lejeuneaceae. I. Introduction; keys to subfamilies and genera. - Journal of the Elisha Mitchell Scientific Society 71(1): 106-126.

SCHUSTER, R.M. 1955. North American Lejeuneaceae. II. Paradoxae: the genera Aphanolejeunea and Leptocolea. - Journal of the Elisha Mitchell Scientific Society 71(1): 126-148.

SCHUSTER, R.M. 1955. North American Lejeuneaceae. III. Paradoxae: Cololejeunea, Sectio Minutissimae. - Journal of the Elisha Mitchell Scientific Society 71(2): 218-247.

SCHUSTER, R.M. 1955. Dr. Karl Müller: an appreciation. - The Bryologist 58(4): 311-316.

SCHUSTER, R.M. 1955. Review of flore générale de Belgique, bryophytes. Vol. 1, Fasc. 1, by C. V. Berghen. - The Bryologist 59(3): 230.

SCHUSTER, R.M. \& H.L. BLOMQUIST. 1955. A comparative study of Telaranea nematodes. - American Journal of Botany 42(7): 588593. https://doi.org/10.2307/2485316 
SCHUSTER, R.M. \& L.E. ANDERSON. 1955. Taxithelium planum (Brid.) Mitt., epiphyllous on Sabal palmetto (Walt.) R. \& S. - The Bryologist 58(3): 237-239. https://doi.org/10.2307/3239911

SCHUSTER, R.M. 1956. North American Lejeuneaceae. IV. Paradoxae: Cololejeunea (concl.), Diplasiolejeunea. - Journal of the Elisha Mitchell Scientific Society 72(1): 87-125.

SCHUSTER, R.M. 1956. Notes on Nearctic hepaticae X. A study of Cephaloziella rhizantha, C. floridae and C. ludoviciana. - The Bryologist 59(2): 130-140. https://doi.org/10.2307/3239927

SCHUSTER, R.M. 1956. Aphanolejeunea cornutissima nom. nov. The Bryologist 59(3): 217-218.

SCHUSTER, R.M. 1956. North American Lejeuneaceae. V. Schizostipae: Ceratolejeunea. - Journal of the Elisha Mitchell Scientific Society 72(2): 292-316.

SCHUSTER, R.M. 1956. Review of a revision of the Japanese species of Scapaniaceae, by T. Amakawa \& S. Hattori. - The Bryologist 59(3): 230-231.

SCHUSTER, R.M. 1956. Review of oil-bodies of Japanese hepaticae, I and II, by S. Hattori. - The Bryologist 59(3): 231.

SCHUSTER, R.M. 1956. Review of die Lebermoose Europas in Rabenhorst's Kryptogamen-flora, VI, by K. Müller. - The Bryologist 59(1): 51-56. https://doi.org/10.2307/3240294

SCHUSTER, R.M. 1956. Review of Marchantiales of Japan, I-IV, by D. Shimizu \& S. Hattori. - The Bryologist 59(3): 232.

SCHUSTER, R.M. 1957. Boreal hepaticae, a manual of the liverworts of Minnesota and adjacent regions. II. Ecology. - The American Midland Naturalist 57(1-2): 203-299.

SCHUSTER, R.M. 1957. North American Lejeuneaceae. VI. Lejeunea: introduction and keys; subgenus Lejeunea (I). - Journal of the Elisha Mitchell Scientific Society 73(1): 122-197.

SCHUSTER, R.M. 1957. North American Lejeuneaceae. VI. Lejeunea: subgenus Lejeunea (II, concluded). - Journal of the Elisha Mitchell Scientific Society 73(2): 388-443.

SCHUSTER, R.M. 1957. Notes on Nearctic hepaticae. XII. Marsupella paroica n. sp. - The Bryologist 60(2): 145-151.

SCHUSTER, R.M. 1957. Notes on Nearctic hepaticae, IX. A study of Plagiochila yokogurensis Steph. - Journal of the Hattori Botanical Laboratory 18: 14-26.

SCHUSTER, R.M. 1957. Notes on Nearctic hepaticae, XV. Herberta.Revue Bryologique et Lichénologique 26: 123-145.

SCHUSTER, R.M. \& P.M. PATTERSON. 1957. Noteworthy hepaticae from Virginia. - Rhodora 59: 251-259.

SCHUSTER, R.M. 1958. Boreal hepaticae, a manual of the liverworts of Minnesota and adjacent regions. III. Phytogeography. - The American Midland Naturalist 59(2): 257-332.

SCHUSTER, R.M. 1958. Notes on Nearctic hepaticae. XIII. The genus Tritomaria (Lophoziaceae) in Arctic Canada. - Canadian Journal of Botany 36(2): 269-288

SCHUSTER, R.M. 1958. Keys to the orders, families and genera of hepaticae of America north of Mexico. - The Bryologist 61(1): 1-66.

SCHUSTER, R.M. 1958. Notes on Nearctic hepaticae, XIV. The Chonecoleaceae. - Journal of the Hattori Botanical Laboratory 20: 1-16.

SCHUSTER, R.M. 1958. Notes on Nearctic hepaticae VI. Phytogeographical relationships of critical species in Minnesota and adjacent areas of the Great Lakes. - Rhodora 60: 243-256.

SCHUSTER, R.M. \& W.C. STEERE. 1958. Hygrolejeunea alaskana sp. n., a critical endemic of northern Alaska. - Bulletin of the Torrey Botanical Club 85(3): 188-196.

SCHUSTER, R.M. 1959. Evolution in the Ptilidiinae. - Proceedings of the IX International Botanical Congress, Montreal 2: 350.

SCHUSTER, R.M. 1959. Epiphyllous hepaticae in the southern Appalachians. - The Bryologist 62(1): 52-55.

SCHUSTER, R.M. 1959. Studies on hepaticae. I. Temnoma. - The Bryologist 62(4): 233-242.
SCHUSTER, R.M., W.C. STEERE \& J.W. THOMSON. 1959. The terrestrial cryptogams of northern Ellesmere Island. - National Museum of Canada Bulletin 164: 1-132.

SCHUSTER, R.M. 1959. A monograph of the Nearctic Plagiochilaceae. I. Introduction and Sectio I. Asplenioides. - The American Midland Naturalist 62: 1-166.

SCHUSTER, R.M. 1959. A monograph of the Nearctic Plagiochilaceae. Part II. Sectio Zonatae through Sectio Parallelae. - The American Midland Naturalist 62(2): 257-395.

SCHUSTER, R.M. 1960. A monograph of the Nearctic Plagiochilaceae. Part III. Sectio Contiguae to conclusion. - The American Midland Naturalist 63(1): 1-130.

SCHUSTER, R.M. 1960. Alexander W. Evans (1868-1959). - Revue Bryologique et Lichénologique 29: 132-139.

SCHUSTER, R.M. 1960. Alexander W. Evans - an appreciation. - The Bryologist 63: 73-81.

SCHUSTER, R.M. 1960. Studies on hepaticae. II. The new family Chaetophyllopsidaceae. - Journal of the Hattori Botanical Laboratory 23: $68-76$.

SCHUSTER, R.M. 1960. Notes on Nearctic hepaticae, XIX. The relationships of Blepharostoma, Temnoma and Lepicolea, with description of Lophochaete and Chandonanthus subg. Tetralophozia, subg. n. - Journal of the Hattori Botanical Laboratory 23: 192-210.

STEERE, W.C. \& R.M. SCHUSTER. 1960. The hepatic genus Ascidiota Massalongo new to North America. - Bulletin of the Torrey Botanical Club 87: 209-215.

SCHUSTER, R.M. 1961. Notes on Nearctic hepaticae. XVIII. New Lophoziaceae from the Arctic Archipelago of Canada. - Canadian Journal of Botany 39: 965-992.

SCHUSTER, R.M. 1961. Studies in Lophoziaceae. I. The genera Anastrophyllum and Sphenolobus and their segregates. - Revue Bryologique et Lichénologique 30: 55-73.

SCHUSTER, R.M. 1961. Studies on hepaticae III-VI. - The Bryologist 64: 198-208.

SCHUSTER, R.M. 1961. The genera Thysananthus, Ptychocoleus, Tuzibeanthus, Phragmilejeunea and Brachiolejeunea (Lejeuneaceae Holostipae). - The Bryologist 64: 156-167.

KACHROO, P. \& R.M. SCHUSTER. 1961. The genus Pycnolejeunea and its affinities to Cheilolejeunea, Euosmolejeunea, Nipponolejeunea, Tuyamaella, Siphonolejeunea, and Strepsilejeunea. - Journal of the Linnean Society. Botany 56: 475-511.

SCHUSTER, R.M. 1962. North American Lejeuneaceae. VII. Lejeunea (Lejeunea) blomquistii sp. nov. - Journal of the Elisha Mitchell Scientific Society 78: 64-68.

SCHUSTER, R.M. 1962. A study of Cephaloziopsis with special reference to C. pearsoni and its distribution. - Transactions of the British Bryological Society 4: 230-246.

SCHUSTER, R.M. 1962. North American Lejeuneaceae. VIII. Lejeunea, subgenera Microlejeunea and Chaetolejeunea. - Journal of the Hattori Botanical Laboratory 25: 1-80.

SCHUSTER, R.M. 1963. An annotated synopsis of the genera and subgenera of Lejeuneaceae. I. Introduction; annotated keys to subfamilies and genera. - Beihefte zur Nova Hedwigia 9: 1-203.

SCHUSTER, R.M. 1963. Studies on hepaticae XI-XIII. On Temnoma, Vetaforma and Lophochaete (Blepharostomaceae; hepaticae). - Nova Hedwigia 5: 27-46.

SCHUSTER, R.M. 1963. Studies on antipodal hepaticae. I. Annotated keys to the genera of antipodal hepaticae with special reference to New Zealand and Tasmania. - Journal of the Hattori Botanical Laboratory 26: $185-309$.

SCHUSTER, R.M. 1964. Studies on hepaticae. XIX.-XX. Cephaloziopsis (Spr.) Schiffn. and Andrewsianthus Schust. - Nova Hedwigia 8: 201-209.

SCHUSTER, R.M. 1964. Studies on hepaticae. XXI. Cephaloziaceae, with particular reference to Metahygrobiella Schust. and Cephalozia Dumort. - Nova Hedwigia 8: 211-223. 
SCHUSTER, R.M. 1964. Studies on hepaticae. XXII.-XXV. Pleurocladopsis Schust., gen. n., Eoisotachis Schust., gen. n., Grollea Schust., gen. n., with critical notes on Anthelia Dumort. - Nova Hedwigia 8: 275-296.

SCHUSTER, R.M. 1964. Studies on hepaticae. XVII. Trichotemnoma Schust., gen. n. - Journal of the Hattori Botanical Laboratory 27: 149-158.

SCHUSTER, R.M. 1964. Studies on antipodal hepaticae, IV. Metzgeriales. - Journal of the Hattori Botanical Laboratory 27: 183-216.

SCHUSTER, R.M. 1964. Studies on hepaticae XIV. The genus Austrolophozia Schust. - The Bryologist 67: 179-186.

SCHUSTER, R.M. 1964. Studies on antipodal hepaticae. VI. The suborder Perssoniellinae: morphology, anatomy and possible evolution. Bulletin of the Torrey Botanical Club 91: 479-490.

SCHUSTER, R.M. 1965. North American Lejeuneaceae. IX. Taxilejeunea. - Journal of the Elisha Mitchell Scientific Society 81: 32-50.

SCHUSTER, R.M. 1965. Studies on antipodal hepaticae. II. Archeophylla Schuster and Archeochaete Schuster, new genera of Blepharostomaceae. - Transactions of the British Bryological Society 4: 801-817.

SCHUSTER, R.M. 1965. Studies on hepaticae. XVI. The morphology and systematic position of the suborder Pleuroziinae. - Transactions of the British Bryological Society 4: 794-800.

SCHUSTER, R.M. 1965. A note on Lejeunea capensis. - Transactions of the British Bryological Society 4: 831 .

SCHUSTER, R.M. 1965. Studies on hepaticae. XXVI. The BonneriaParacromastigum-Pseudocephalozia-Hyalolepidozia-ZoopsisPteropsiella complex and its allies: a phylogenetic study (part 1).Nova Hedwigia 10: 19-61.

SCHUSTER, R.M. 1965. Studies on antipodal hepaticae, VII. Goebeliellaceae. - Journal of the Hattori Botanical Laboratory 28: 129-138.

SCHUSTER, R.M. 1965. Studies on hepaticae, XXVII. Xenocephalozia Schust. - Journal of the Hattori Botanical Laboratory 28: 139-145.

SCHUSTER, R.M. 1966. A memoir on the family Blepharostomataceae, I. - Candollea 21: 59-136.

SCHUSTER, R.M. 1966. The hepaticae and Anthocerotae of North America east of the hundredth meridian. Vol. I. - New York, Columbia University Press, 1-802 pp.

SCHUSTER, R.M. 1966. Studies in Lophoziaceae. 1. The genera Anastrophyllum and Sphenolobus and their segregates. 2. Cephalolobus gen. n., Acrolophozia gen. n. and Protomarsupella gen. n. - Revue Bryologique et Lichénologique 34: 240-287.

SCHUSTER, R.M. 1966. Studies on hepaticae, XXVIII. On Phycolepidozia, a new, highly reduced genus of Jungermanniales of questionable affinity. - Bulletin of the Torrey Botanical Club 93: 437-449.

SCHUSTER, R.M. 1966. A memoir on the family Blepharostomataceae, II. - Candollea 21: 241-355.

SCHUSTER, R.M. 1966. On Adelanthus Mitten: a case of the international rules versus the international rules. - Nova Hedwigia 12: 353-361.

SCHUSTER, R.M. 1966. Studies on hepaticae, VII-X. On Adelanthus Mitten and Calyptrocolea Schuster, gen. n. - Revue Bryologique et Lichénologique 34: 676-703.

SCHUSTER, R.M. 1967. North American Lejeuneaceae. X. Harpalejeunea, Drepanolejeunea, and Leptolejeunea. - Journal of the Elisha Mitchell Scientific Society 83: 192-229.

SCHUSTER, R.M. 1967. A note on the genus Gymnocolea Dum. - The Bryologist 70: 111-112.

SCHUSTER, R.M. 1967. Studies on hepaticae XV. Calobryales. - Nova Hedwigia 13: 1-63.

SCHUSTER, R.M. 1967. Studies on antipodal hepaticae. IX. Phyllothalliaceae. - Transactions of the British Bryological Society 5: 283-288.

SCHUSTER, R.M. 1968. Introduction to H. Leitgeb, Untersuchungen Uber die Lebermoose. - Lehre, J. Cramer, 1-8 pp.

SCHUSTER, R.M. 1968. Studies on antipodal hepaticae, X. Subantarctic Scapaniaceae, Balantiopsidaceae and Schistochilaceae. - Bulletin of the National Science Museum 11: 13-31.
SCHUSTER, R.M. 1968. Studies on hepaticae. XLV. On Iwatsukia Kitagawa. - Bulletin of the National Science Museum 11: 309-317.

SCHUSTER, R.M. 1968. Studies on hepaticae, XXIX-XLIV. A miscellany of new taxa and new range extensions. - Nova Hedwigia 15: 437-529.

SCHUSTER, R.M. 1969. Problems of antipodal distribution in lower land plants. - Taxon 18: 46-91

SCHUSTER, R.M. 1969. Results of bryological field work in the Antarctic Peninsula, austral summer. 1968-1969. - Antarctic Journal of the United States 4: 103-104.

SCHUSTER, R.M. 1969. Studies on hepaticae. XLVIII. On Anomacaulis Schust. - Transactions of the British Bryological Society 5: 797-799.

SCHUSTER, R.M. 1969. Studies on hepaticae, XLVI-XLVII. On Alobiella (Spr.) Schiffn. and Alobiellopsis Schust. - Bulletin of the National Science Museum 12: 659-683.

SCHUSTER, R.M. 1969. The hepaticae and Anthocerotae of North America east of the hundredth meridian. Vol. II. - New York, Columbia University Press, 1-1062 pp.

SCHUSTER, R.M. 1969. Anomomarsupella, a new genus of Gymnomitriaceae from Greenland. - Nova Hedwigia 17: 75-82.

SCHUSTER, R.M. \& G.A.M. SCOTT. 1969. A study of the family Treubiaceae (hepaticae; Metzgeriales). - Journal of the Hattori Botanical Laboratory 32: 219-268.

SCHUSTER, R.M. 1970. Studies on antipodal hepaticae, III. Jubulopsis Schuster, Neohattoria Kamimura and Amphijubula Schuster. - Journal of the Hattori Botanical Laboratory 33: 266-304.

SCHUSTER, R.M. 1970. Studies on hepaticae. XVIII. The family Jungermanniaceae, s. lat.: a reclassification. - Transactions of the British Bryological Society 6: 86-107.

SCHUSTER, R.M. 1970. Review of manual of the leafy hepaticae of Latin America. Part III, by M. H. Fulford. - Transactions of the British Bryological Society 6: 161-164.

SCHUSTER, R.M. 1970. Studies on hepaticae, XLIX-LIII. New Lejeuneaceae from Dominica and Jamaica. - Bulletin of the Torrey Botanical Club 97: 336-352.

SCHUSTER, R.M. 1971. The ecology and distribution of hepaticae in a Mahogany Hammock in tropical Florida. - Castanea 36: 90-111.

SCHUSTER, R.M. 1971. Two new antipodal species of Haplomitrium (Calobryales). - The Bryologist 74: 131-143.

SCHUSTER, R.M. 1971. Studies of antipodal Schistochilaceae and Scapaniaceae. - Bulletin of the National Science Museum 14: 609-660.

SCHUSTER, R.M. 1971. On the genus Pleurocladopsis Schuster (Schistochilaceae). - The Bryologist 74: 493-495.

SCHUSTER, R.M. 1971. Studies on Cephaloziellaceae. - Nova Hedwigia 22: 121-265.

SCHUSTER, R.M. 1971. Studies on Cephaloziellaceae. II. Cylindrocolea madagascariensis. - Nova Hedwigia 22: $266 a-c$.

INOUE, H. \& R. M. SCHUSTER. 1971. A monograph of New Zealand and Tasmanian Plagiochilaceae. - Journal of the Hattori Botanical Laboratory 34: 1-225.

SCHUSTER, R.M. 1972. Continental movements, "Wallace's Line," and Indomalayan-Australasian dispersal of land plants: some eclectic concepts. - Botanical Review, Interpreting Botanical Progress 38: 3-86.

SCHUSTER, R.M. 1972. Evolving taxonomic concepts in the hepaticae, with special reference to circum-pacific taxa. - Journal of the Hattori Botanical Laboratory 35: 169-201.

SCHUSTER, R.M. 1972. Phylogenetic and taxonomic studies on Jungermanniidae. - Journal of the Hattori Botanical Laboratory 36: 321-405.

SCHUSTER, R.M. \& K. DAMSHOLT. 1972. Lophozia (Orthocaulis) hyperborea (Schust.) Schust. in southwest Greenland. - Lindbergia 1: $166-168$.

ENGEL, J.J. \& R.M. SCHUSTER. 1973. On some tidal zone hepaticae from south Chile, with comments on marine dispersal. - Bulletin of the Torrey Botanical Club 100: 29-35. 
ENGEL, J.J. \& R.M. SCHUSTER. 1973. Austral hepaticae I. Pigafettoa Mass. - The Bryologist 76: 511-515.

SCHUSTER, R.M. \& J.J. ENGEL. 1973. Austral hepaticae II. Evansianthus, a new genus of Geocalycaceae. - The Bryologist 76: 516-520.

SCHUSTER, R.M. 1973. A note on Scapania perssonii Schust. - The Bryologist 76: 572-573.

SCHUSTER, R.M. 1974. The hepaticae and Anthocerotae of North America east of the hundredth meridian. Vol. III. - New York, Columbia University Press, $1-880 \mathrm{pp}$.

SCHUSTER, R.M. 1974. Studies on antipodal hepaticae XI. The Chaetophyllopsidaceae: their taxonomy, phylogeny and phytogeographic affinities. - Bulletin of the National Science Museum 17: 163-180.

SCHUSTER, R.M. 1974. Review of illustrations of Japanese hepaticae, by H. Inoue. - The Bryologist 77: 659-660.

ENGEL, J.J. \& R.M. SCHUSTER. 1974. A monograph of the genus Pseudocephalozia (hepaticae). - Journal of the Hattori Botanical Laboratory 38: 665-701.

SCHUSTER, R.M. \& H. INOUE. 1974. Cololejeunea subgen. Chlorolejeunea Benedix in Japan. - Bulletin of the National Science Museum 17: $233-238$.

SCHUSTER, R.M. \& K. DAMSHOLT. 1974. The hepaticae of west Greenland from ca. 66 s N to 72 ș. - Meddelelser om Grřnland, udgivne af Kommissionen for Ledelsen af de Geologiske og Geografiske Underšrgelser i Grřnland 199: 1-373.

INOUE, H. \& R. M. SCHUSTER. 1974. The taxonomic status of the genus Metacephalozia Inoue. - Bulletin of the National Science Museum 17: 161-162.

SCHUSTER, R.M. \& J.J. ENGEL. 1975. Austral hepaticae V. Studies on Schistochilaceae. - Phytologia 30: 241-250.

ENGEL, J.J. \& R.M. SCHUSTER. 1975. Austral hepaticae III. Stolonopho$r a$, a new genus of Geocalycaceae. - Fieldiana. Botany. 36: 111-124.

SCHUSTER, R.M. \& H. INOUE. 1975. Studies on Pallaviciniaceae and Allisoniaceae (Metzgeriales) in Japan. 1. Introduction and genus Hattorianthus, gen. nov. - Bulletin of the National Science Museum. Series $B$, Botany I: 101-107.

SCHUSTER, R.M. \& J.J. ENGEL. 1975. Austral hepaticae, IV. Notes on Lophozia subgenus Protolophozia Schust., with diagnosis of a new South American species. - Journal of Bryology 8: 465-474.

SCHUSTER, R.M. 1976. Plate tectonics and its bearing on the geographical origin and dispersal of angiosperms. $-I n:$ Beck, C. B. (ed.), Origin and Early Evolution of Angiosperms. Columbia University Press, New York: 48-138.

SCHUSTER, R.M. 1976. Review of a taxonomic monograph of the genus Acrolejeunea (hepaticae), by S.R. Gradstein. - The Bryologist 79(3): 380-382.

SCHUSTER, R.M. 1977. The evolution and early diversification of the hepaticae and Anthocerotae. - In: Frey, W., H. Hurka \& F. Overwinkler (eds.). Beiträge zur Biologie der niederen Pflanzen. Fischer Verlag, Stuttgart: 107-115.

SCHUSTER, R.M. 1977. Review of a monograph of the genus Bryopteris (Swartz) Nees von Esenbeck, by R.E. Stotler \& B. Crandall-Stotler. - The Bryologist 80: 555-556.

SCHUSTER, R.M. \& J. ENGEL. 1977. Austral hepaticae, V. The Schistochilaceae of South America. - Journal of the Hattori Botanical Laboratory 42: 273-423.

SCHUSTER, R.M. 1978. Studies on Venezuelan hepaticae, I. - Phytologia 39: 239-251.

SCHUSTER, R.M. 1978. Studies on Venezuelan hepaticae, II. - Phytologia 39: 425-432.

SCHUSTER, R.M. \& O. MARTENSSON. 1978. The genus Cryptocolea (Jungermanniales) new for Europe. - Lindbergia 4: 203-205.

SCHUSTER, R.M. 1979. The phylogeny of the hepaticae. - In: G. C. Clarke \& J. G. Duckett (eds.). Bryophyte Systematics. Systematics Assoc. Special Vol. 14. Academic Press, London and New York: 41-82.
SCHUSTER, R.M. 1979. On the persistence and dispersal of transantarctic hepaticae. - Canadian Journal of Botany 57: 2179-2225.

SCHUSTER, R.M. 1980. New combinations and taxa of hepaticae, I. Phytologia 45: 415-437.

SCHUSTER, R.M. 1980. Studies on hepaticae, LIV-LVIII. Kurzia v. Mart. [Microlepidozia (Spr.) Joerg.], Megalembidium Schust., Psiloclada Mitt., Drucella Hodgs., and Isolembidium Schust. - Journal of the Hattori Botanical Laboratory 48: 337-421.

SCHUSTER, R.M. 1980. The hepaticae and Anthocerotae of North America east of the hundredth meridian. Vol. IV. - New York, Columbia University Press, 1-1334 pp.

SCHUSTER, R.M. 1980. Phylogenetic studies on Jungermanniidae. II. Radulineae (Part I). - Nova Hedwigia 32: 637-693.

SCHUSTER, R.M. 1981. Austral hepaticae, VIII. Tuyamaelloideae.Phytologia 47: 301-308.

SCHUSTER, R.M. \& J.J. ENGEL. 1981. Austral hepaticae XIII. Two new genera of Geocalycaceae (Lophocoleaceae. - Phytologia 47: 309-312.

ENGEL, J.J. \& R.M. SCHUSTER. 1981. Austral hepaticae XV. Brevianthaceae, fam. nov. and Brevianthus, gen. nov. from Tasmania. - Phytologia 47: 317-318.

SCHUSTER, R.M. 1981. Late Pleistocene bryological relicts in western Massachusetts. -Rhodora 83: 441-448.

SCHUSTER, R.M. 1981. Paleoecology, origin, distribution through time, and evolution of hepaticae and Anthocerotae. - In: K. J. Niklas (ed.), Paleobotany, Paleoecology, and Evolution. Vol. 2. Praeger, New York: 129-191.

SCHUSTER, R.M. 1981. Studies on hepaticae, LIX. Anastrepta (Lindb.) Schiffn. and Nothostrepta Schust. - Journal of the Hattori Botanical Laboratory 50: 83-94.

SCHUSTER, R.M. 1981. Evolution and speciation in Pellia, with special reference to the Pellia megaspora-endiviifolia complex (Metzgeriales), I. Taxonomy and distribution. - Journal of Bryology 11: 411-431.

SCHUSTER, R.M. 1982. Richard Spruce (1817-1893): a biographical sketch and appreciation. - Nova Hedwigia 36: 199-208.

SCHUSTER, R.M. 1982. Exogenous branching and its phylogenetic significance in Calobryales and Jungermanniales. - Journal of the Hattori Botanical Laboratory 51: 1-50.

SCHUSTER, R.M. 1982. Studies on hepaticae, LIX. On Sandeothallus Schust., gen. n. and the classification of the Metzgeriales. - Nova Hedwigia 36: 1-16.

SCHUSTER, R.M. 1982. Generic and familial endemism in the hepatic flora of Gondwanaland: origins and causes. - Journal of the Hattori Botanical Laboratory 52: 3-35.

SCHUSTER, R.M. \& J.J. ENGEL. 1982. Austral hepaticae XVI. Gondwanalandic Leptoscyphoideae (Geocalycaceae). - Lindbergia 8: 65-74.

SCHUSTER, R.M. \& J.J. ENGEL. 1982. Austral hepaticae XVII. Pachyschistochila Schust. et Engel, gen. nov. - Phytologia 50: 177-180.

ENGEL, J.J. \& R.M. SCHUSTER. 1982. Austral hepaticae XV. Brevianthaceae: a monotypic family endemic to Tasmania. - The Bryologist 85: $375-388$

SCHUSTER, R.M. \& W.B. SCHOFIELD. 1982. On Dendrobazzania, a new genus of Lepidoziaceae (Jungermanniales). - The Bryologist $\mathbf{8 5}$ : 231-238.

SCHUSTER, R.M. 1983. Reproductive biology, dispersal mechanisms, and distribution patterns in hepaticae and Anthocerotae. $-I n: K . K u-$ bitzki (ed.), Dispersal and Distribution: An International Symposium. Sonderbd. Naturwiss. Ver. Hamburg 7. Hamburg: 119-162.

SCHUSTER, R.M. 1983. Notes on Nearctic hepaticae, XVI. New taxa of Frullania from eastern North America. - Phytologia 53: 364-366.

SCHUSTER, R.M. 1983. New Manual of Bryology. Vol. 1. - In: Schuster, R.M. (ed.). Hattori Botanical Laboratory, Nichinan: 1-626.

LONGTON, R.E. \& R.M. SCHUSTER. 1983. Reproductive Biology. In: Schuster, R.M. (ed.). New Manual of Bryology. Vol. 1. Hattori Botanical Laboratory, Nichinan: 386-462. 
SCHUSTER, R.M. 1983. Phytogeography of the Bryophyta. - In: Schuster, R.M. (ed.). New Manual of Bryology. Vol. 1. Hattori Botanical Laboratory, Nichinan: 463-626.

ENGEL, J.J. \& R.M. SCHUSTER. 1983. Austral hepaticae XVIII. Studies toward a revision of Telaranea subg. Neolepidozia (Lepidoziaceae). - Fieldiana. Botany. new series 14: 1-7.

SCHUSTER, R.M. 1984. New manual of bryology. Vol. 2. - In: Schuster, R.M. (ed.). Hattori Botanical Laboratory, Nichinan: 627-1295.

SCHUSTER, R.M. 1984. Comparative anatomy and morphology of the hepaticae. - In: Schuster, R.M. (ed.). New Manual of Bryology. Vol. 2. Hattori Botanical Laboratory, Nichinan: 760-891.

SCHUSTER, R.M. 1984. Evolution, phylogeny and classification of the hepaticae. - In: Schuster, R.M. (ed.). New Manual of Bryology. Vol. 2. Hattori Botanical Laboratory, Nichinan: 892-1070.

SCHUSTER, R.M. 1984. Morphology, phylogeny and classification of the Anthocerotae. -In: Schuster, R.M. (ed.). New Manual of Bryology. Vol. 2. Hattori Botanical Laboratory, Nichinan: 1071-1092.

KRASSILOV, V.A. \& R.M. SCHUSTER. 1984. Paleozoic and Mesozoic fossils. - In: Schuster, R.M. (ed.). New Manual of Bryology. Vol. 2. Hattori Botanical Laboratory, Nichinan: 1172-1193.

SCHUSTER, R.M. 1984. Diagnoses of some new taxa of hepaticae. Phytologia 56: 65-74.

ENGEL, J.J. \& R.M. SCHUSTER. 1984. An overview and evaluation of the genera of Geocalycaceae subfamily Lophocoleoideae (hepaticae). - Nova Hedwigia 39: 385-463.

SCHUSTER, R.M. 1985. Austral hepaticae, XIX. Some taxa new to New Zealand and New Caledonia. - Phytologia 56: 449-464.

SCHUSTER, R.M. 1985. Studies on Porellineae: New taxa of Jubulaceae. - Phytologia 57: 369-373

SCHUSTER, R.M. 1985. Some new taxa of hepaticae. - Phytologia 57 : 408-414.

SCHUSTER, R.M. 1985. Studies on Venezuelan hepaticae III. Families Blepharostomataceae and Balantiopsidaceae. - Nova Hedwigia 42: 49-79.

SCHUSTER, R.M. \& J.J. ENGEL. 1985. Austral hepaticae V (2). Temperate and subantarctic Schistochilaceae of Australasia. - Journal of the Hattori Botanical Laboratory 58: 255-539.

SCHUSTER, R.M. 1986. On the status of Cephalozia macrantha Kaal. \& Nichols. and C. patagonica Fulford. - Lindbergia 12: 1-4.

SCHUSTER, R.M. 1986. Gymnocolea borealis (Frisvoll \& Moen) Schust. [Lophozia (Leiocolea) borealis Frisvoll \& Moen] in North America. Lindbergia 12: 5-8.

SCHUSTER, R.M. 1987. On Aureolejeunea Schust. and Brachiolejeunea paramicola Herzog. - Phytologia 61: 445-447.

SCHUSTER, R.M. \& J.J. ENGEL. 1987. Austral hepaticae XX. New species of Hygrolembidium (Lepidoziaceae). - Phytologia 62: 9-12.

SCHUSTER, R.M. \& J.J. ENGEL. 1987. A monograph of Lepidoziaceae subfam. Lembidioideae (hepaticae). - Journal of the Hattori Botanical Laboratory 63: 247-350.

SCHUSTER, R.M. \& K. DAMSHOLT. 1987. Some new taxa of Jungermanniales. - Phytologia 63: 325-328.

SCHUSTER, R.M. 1987. Studies on Metzgeriales: I. North American Aneuraceae. - Journal of the Hattori Botanical Laboratory 62: 299-329.

SCHUSTER, R.M. 1987. Venezuelan hepaticae IV. Amphilejeunea Schust. and Aureolejeunea Schust. - Nova Hedwigia 44: 1-23.

SCHUSTER, R.M. 1987. Preliminary studies on Anthocerotae. - Phytologia 63: 193-201.

SCHUSTER, R.M. 1987. Phylogenetic studies on Jungermanniidae. II. Mastigophoraceae and Chaetophyllopsidaceae. - Memoirs of the New York Botanical Garden 45: 733-748.

SCHUSTER, R.M. 1988. The hepaticae of south Greenland. - Beihefte zur Nova Hedwigia 92: 1-255.

SCHUSTER, R.M. 1988. The aims and achievements of bryophyte taxonomists. - Journal of the Linnean Society. Botany 98: 185-202.
SCHUSTER, R.M. 1988. Ecology, reproductive biology and dispersal of hepaticae in the tropics. - Journal of the Hattori Botanical Laboratory 64: 237-269.

ENGEL, J. \& R.M. SCHUSTER. 1988. Studies of New Zealand hepaticae. 1-6. - Brittonia 40: 200-207.

SCHUSTER, R.M. 1989. Studies on the hepatic flora of the Prince Edward Islands. I. Aneuraceae. - Journal of the Hattori Botanical Laboratory 67: 59-108.

SCHUSTER, R.M. \& J.A. JANSSENS. 1989. On Diettertia, an isolated Mesozoic member of the Jungermanniales. - Review of Palaeobotany and Palynology 57: 277-287.

SCHUSTER, R.M. 1990. Origins of neotropical leafy hepaticae. - Tropical Bryology 2: 239-264.

SCHUSTER, R.M. 1991. On neotenic species of Radula. - Journal of the Hattori Botanical Laboratory 70: 51-62.

SCHUSTER, R.M. 1991. Diagnoses of new taxa of hepaticae. I. Jungermanniidae. - Journal of the Hattori Botanical Laboratory 70: 143-150.

SCHUSTER, R.M. 1991. Studies on Venezuelan hepaticae V. On Pseudocephaloziella Schust. (Jungermanniaceae subf. Lophozioideae). - Nova Hedwigia 53: 331-339.

SCHUSTER, R.M. 1992. Studies on Marchantiales, I-III. - Journal of the Hattori Botanical Laboratory 71: 267-287.

SCHUSTER, R.M. 1992. The hepaticae and Anthocerotae of North America. Vol. V. - Chicago, Field Museum, 1-854 pp.

SCHUSTER, R.M. 1992. The hepaticae and Anthocerotae of North America. Vol. VI. - Chicago, Field Museum, 1-937 pp.

SCHUSTER, R.M. 1992. On Megaceros aenigmaticus Schust. - The Bryologist 95: 305-315.

SCHUSTER, R.M. 1992. The oil-bodies of the hepaticae. I. Introduction. - Journal of the Hattori Botanical Laboratory 72: 151-162.

SCHUSTER, R.M. 1992. The oil-bodies of the hepaticae. II. Lejeuneaceae. - Journal of the Hattori Botanical Laboratory 72: 163-359.

SCHUSTER, R.M. \& C. GIANCOTTI. 1993. On Vitalianthus Schust. \& Giancotti, a new genus of Lejeuneaceae. - Nova Hedwigia 57: 445-456.

SCHUSTER, R.M. 1993. Studies on hepaticae, LXII-LXIV. Lepidoziaceae subf. Zoopsidoideae (1). - Nova Hedwigia 56: 35-59.

SCHUSTER, R.M. 1993. On Cephalozia pachycaulis sp. nov. and the perimeters of Cephalozia. - The Bryologist 96: 619-625.

SCHUSTER, R.M. 1994. Studies on Metzgeriales. III. The classification of the Fossombroniaceae and on Austrofossombronia Schust., gen. n. Hikobia 11: 439-449.

SCHUSTER, R.M. 1994. Studies on Lejeuneaceae, I. Preliminary studies on new genera of Lejeuneaceae. - Journal of the Hattori Botanical Laboratory 75: 211-235.

ENGEL, J. \& R.M. SCHUSTER. 1994. Studies of New Zealand hepaticae. 7. The status of Steereomitrium. - The Bryologist 97: 63-66.

SCHUSTER, R.M. 1994. Review of paleobotany and the evolution of plants. Second Edition, by W.N. Stewart \& G.W. Rothwell. - The Bryologist 97: 463-464.

SCHUSTER, R.M. 1995. Studies on Cephaloziellaceae III. On Cephalomitrion Schust., gen. n. - Nova Hedwigia 61: 547-559.

SCHUSTER, R.M. 1995. Notes on Nearctic hepaticae. XX. On Schofieldia and evolution in the Cephalozioideae. - Fragmenta Floristica et Geobotanica 40: 39-46.

SCHUSTER, R.M. 1995. Venezuelan hepaticae VI. On Platycaulis Schust. (Jungermanniales). - Nova Hedwigia 61: 391-396.

SCHUSTER, R.M. \& N. KONSTANTINOVA. 1995. Studies on Treubiales, I. On Apotreubia Hatt. et al. and A. hortonae Schust. \& Konstantinova, sp. n. - Journal of the Hattori Botanical Laboratory 78: 41-61.

SCHUSTER, R.M. 1995. The hepaticae of Prince Edward Islands. II. On Gymnocoleopsis (Schust.) Schust., Lophozia cylindriformis (Mitt.) Steph. and the subgeneric classification of the genus Lophozia Dumort. - Journal of the Hattori Botanical Laboratory 78: 119-135. 
SCHUSTER, R.M. 1995. Phylogenetic and taxonomic studies on Jungermanniidae, III. Calypogeiaceae. - Fragmenta Floristica et Geobotanica 40: $825-888$.

SCHUSTER, R.M. \& A. SCHAFER-VERWIMP. 1995. On Pluvianthus (Lejeuneaceae: Lejeuneoideae). - Nova Hedwigia 60: 59-72.

SCHUSTER, R.M. 1995. On a new species of Gymnomitrion, G. mucrophorum Schust., sp. n. - The Bryologist 98: 242-245.

SCHUSTER, R.M. 1995. Notes on Nearctic hepaticae, XVII. Lophozia decolorans, new to North America and the subgenus Isopaches. - The Bryologist 98: 246-250.

SCHUSTER, R.M. 1996. Studies on Cephaloziellaceae IV. On New Zealand taxa. - Nova Hedwigia 63: 1-61.

SCHUSTER, R.M. 1996. Studies on Lejeuneaceae, II. Neotropical taxa of Drepanolejeunea (Spr.) Schiffn. - Nova Hedwigia 62: 1-46.

SCHUSTER, R.M. \& J.J. ENGEL. 1996. Austral hepaticae. XXI. Paracromastigum fiordlandiae (sp. nov.) and the delimitation of Paracromastigum and Hyalolepidozia (Lepidoziaceae). - Brittonia 48: 165-173.

SCHUSTER, R.M. 1996. Venezuelan hepaticae VI. On Lophonardia Schust. - Nova Hedwigia 62: 437-442.

SCHUSTER, R.M. 1996. Studies on antipodal hepaticae. XII. Gymnomitriaceae. - Journal of the Hattori Botanical Laboratory 80: 1-147.

SCHUSTER, R.M. 1996. On Jubulopsis Schust. (Jungermanniales: Jubulopsidaceae fam. nov.) and its relationships. - Journal of Bryology 19: 297-310.

SCHUSTER, R.M. \& N. KONSTANTINOVA. 1996. Studies on the distribution of critical arctic/subarctic hepaticae with special reference to taxa found in Russia. - Lindbergia 21: 26-48.

SCHUSTER, R.M. 1996. On Olgantha Schust., gen. n. Isophylly and evolution of Jungermanniales. - Nova Hedwigia 63: 529-543.

SCHUSTER, R.M. 1997. On Bragginsella, a new genus of Jungermanniales from New Zealand. - The Bryologist 100: 362-367.

SCHUSTER, R.M. 1997. On Campanocolea Schust. and asexual reproduction in the Geocalycaceae. - Journal of the Hattori Botanical Laboratory 82: 253-259.

SCHUSTER, R.M. \& J.J. ENGEL. 1997. Austral hepaticae XXIV. A revision of Isotachis Mitt. (Balantiopsaceae: Isotachidoideae) in New Zealand. - Journal of the Hattori Botanical Laboratory 83: 187-227.

SCHUSTER, R.M. 1997. On a new, microphyllous New Caledonian $A c$ romastigum (Lepidoziaceae). - Nova Hedwigia 64: 613-620.

SCHUSTER, R.M. 1997. On Takakia and the phylogenetic relationships of the Takakiales. - Nova Hedwigia 64: 681-310.

SCHUSTER, R.M. 1997. On Anastrophyllum stellatum Schust. (Jungermanniaceae, Lophozioideae). - Journal of the Hattori Botanical Laboratory 83: 229-235.

GLENNY, D., J. BRAGGINS \& R.M. SCHUSTER. 1997. Zoopsis niti$d a$ (hepaticae: Lepidoziaceae), a new species from New Zealand. Journal of Bryology 19: 775-780.

SCHUSTER, R.M. 1998. On Lejeunea (Papillolejeunea) pocsii Schust., sp. n. of New Zealand. - Journal of the Hattori Botanical Laboratory 85: $83-87$

SCHUSTER, R.M. 1998. Venezuelan hepaticae VII. Leptoscyphopsis Schust., a genus seemingly intermediate between Geocalycaceae and Plagiochilaceae (Jungermanniales). - Journal of the Hattori Botanical Laboratory 85: 89-94.

SCHUSTER, R.M. 1998. On the genus Scaphophyllum (Jungermanniaceae). - The Bryologist 101: 428-434.

Supplementary Material: Hepatic taxa described by R.M. Schuster https://kmkjournals.com/upload/PDF/Arctoa/30/Arctoa30_126_137_SM1.pdf
SCHUSTER, R.M. 1999. Studies on hepaticae, LXV. Lepidoziaceae subf. Zoopsidoideae (2): Zoopsis. - Nova Hedwigia 68: 1-63.

SCHUSTER, R.M. 1999. Studies on hepaticae LXVI. Lepidoziaceae subfamily Zoopsidoideae (3): Zoopsidella. - Nova Hedwigia 69: 101-149.

SCHUSTER, R.M. 1999. Studies on hepaticae, LXVII-LXVIII. Lepidoziaceae subfamily Zoopsidoideae (4): Monodactylopsis and Pteropsiella. - Nova Hedwigia 69: 517-540.

SCHUSTER, R.M. 1999. Studies on Jungermanniidae. IV. On Scapaniaceae, Blepharidophyllaceae and Delavayellaceae. - Journal of Bryology 21: 123-132.

SCHUSTER, R.M. 1999. Verdoornia and the phylogeny of the Metzgeriales. - Journal of the Hattori Botanical Laboratory 86: 71-87.

SCHUSTER, R.M. 1999. Harpalejeunea (Spr.) Schiffn. I. Studies on a new Andean species of Harpalejeunea. - Journal of the Hattori Botanical Laboratory 87: 287-294.

SCHUSTER, R.M. 1999. On Neogrollea E. A. Hodgs. (Lepidoziaceae) and the phytogeography of the Lepidoziaceae. - Haussknechtia 9: 333338.

SCHUSTER, R.M. 2000. On the genus Rhodoplagiochila Schust. (Plagiochilaceae). - Nova Hedwigia 71: 395-403.

SCHUSTER, R.M. 2000. Austral hepaticae. Part I. - Beihefte zur Nova Hedwigia 118: 1-524.

SCHUSTER, R.M. 2000. Studies on Lejeuneaceae, II. Rectolejeunea Evs. emend. Schust. (Lejeuneoideae). - Journal of the Hattori Botanical Laboratory 89: 113-150.

SCHUSTER, R.M. 2000. Studies on Lejeuneaceae, III. Revisionary studies on Stenolejeunea Schust. - Journal of the Hattori Botanical Laboratory 89: 151-171.

SCHUSTER, R.M. 2001. Studies on Lejeuneaceae, IV. On the circumscription and subdivision of the subfamily Lejeuneoideae. - Journal of the Hattori Botanical Laboratory 91: 137-172.

SCHUSTER, R.M. 2001. Revisionary studies on austral Acrobolbaceae, I. - Journal of the Hattori Botanical Laboratory 90: 97-166.

SCHUSTER, R.M. 2001. On Amphilophocolea Schust. and Cyanolophocolea (Schust.) Schust., new austral genera of Lophocoleoideae (Geocalycaceae). - Nova Hedwigia 72: 91-104.

SCHUSTER, R.M. 2001. Studies on hepaticae LXI. Trichocoleaceae. Nova Hedwigia 73: 461-486.

ENGEL, J. \& R.M. SCHUSTER. 2001. Austral hepaticae. 32. A revision of the genus Lepidozia (hepaticae) for New Zealand. - Fieldiana. Botany. new series 42: 1-107.

SCHUSTER, R.M. 2002. Revisionary studies of the Chandonanthoideae (Jungermanniales, Jungermanniaceae). - Nova Hedwigia 74: 465-496.

SCHUSTER, R.M. 2002. Austral hepaticae. Part II. - Beihefte zur Nova Hedwigia 119: 1-606.

SCHUSTER, R.M. 2006. Studies on Lejeuneaceae. V. Leucolejeunea and allies. - Journal of the Hattori Botanical Laboratory 100: 361-406.

HENDRY, T.A., B. WANG, Y. YANG, E.C. DAVIS, J.E. BRAGGINS, R.M. SCHUSTER \& Y-L QIU. 2007. Evaluating phylogenetic positions of four liverworts from New Zealand, Neogrollea notabilis, Jackiella curvata, Goebelobryum unguiculatum and Herzogianthus vaginatus, using three chloroplast genes. - The Bryologist 110: 738-751.

SCHUSTER, R.M. 2021. Austral hepaticae. Part III. - Beihefte zur Nova Hedwigia 120: 1-721. 